http://dx.doi.org/10.11646/zootaxa.3795.1.2

http://zoobank.org/urn:lsid:zoobank.org:pub:2785454E-DAD7-4EA2-9D3F-A17F6EE5D6B0

\title{
A new genus and species of Cyproideidae (Crustacea: Peracarida: Amphipoda) from a tropical coral reef, SE Gulf of Mexico
}

\author{
M. ORTIZ \& I. WINFIELD ${ }^{1}$ \\ Laboratorio de Crustáceos, Facultad de Estudios Superiores Iztacala-Universidad Nacional Autónoma de México, Avenida de los \\ Barrios 1, Los Reyes Iztacala, Tlalnepantla, Estado de México, México. \\ 'Corresponding author.E-mail: ignacioc@unam.mx
}

\begin{abstract}
Sisalia carricarti new genus, new species, is described on specimens collected from the Sisal Coral Reef System, Southern Gulf of Mexico, Mexico. The new genus is most morphologically similar to the genus Paracyproidea, but can be distinguished by the article 2 of antenna 2 peduncle, the peduncle of the uropods and length of rami, and telson. Also, the new genus can be distinguished from the rest 18 genera of the family Cyproideidae by the following characteristics: 3-articulate mandible palp, mandible molar big and triturative; palp on maxilla 2 uniarticulate; article 2 of pereopods 3-7 rectilinear, and urosomites 1-3 not elongated. Sisalia carricarti new genus, new species, represents the second known genus and third species of cyproideid amphipods documented from the Inter-American Sea (Gulf of Mexico and Caribbean Sea), and the 19th genus and 44th species of the world cyproideid fauna. The more significant morphological characters and the geographical distribution of the 19 known genera of cyproideid amphipods are also pointed out.
\end{abstract}

Key words: Amphipoda, Cyproideidae, new genus, new species, Sisal coral reef, Mexico, taxonomy

\section{Introduction}

The family Cyproideidae J.L. Barnard, 1974 includes small benthic amphipods that are mainly widespread in the Indo-West Pacific ecosystems (Lowry \& Azman 2008). Cyproideids are morphologically characterized by the coxae 1 and 2 smaller than coxae 3 and 4, these last enlarged and broadened; the uropod 3 biramous with elongated peduncle, and with dorsal keel (Azman 2009). Previously to this work, this family comprised 18 genera and 43 species (Lowry \& Azman 2008) distributed worldwide. Of these species, only Hoplopheonoides obesa Shoemaker and Hoplopheonoides shoemakari Ortiz, Lalana \& Sánchez-Díaz have been documented from the Gulf of Mexico and the Caribbean Sea (LeCroy et al. 2009).

Cyproideids are known to occur mostly in the Southern Hemisphere (Lowry \& Stoddart 2003; Lowry \& Azman 2008) associated with different biological and no-biological substrates (J.L. Barnard 1972; Griffiths 1975; Moore 1981; Myers 1985; Thomas 1999; Ortiz, et al. 2000; Lowry \& Stoddart 2003; Lowry \& Azman 2008) (Table 1).

During an oceanographic campaign carried out in the Sisal Coral Reef System (SAS), SE Gulf of Mexico, Mexico, several lots of peracarids were collected from different biological substrates by SCUBA divers in 2012. Among this material, a series of 5 amphipods of the family Cyproideidae were recognized and represent an undescribed genus and species. This new species was associated with Callithamnion corymbosum, Dictyopteris delicatula and Udotea sp., beds from 2 to $13 \mathrm{~m}$ depth from offshore habitats in the SE Gulf of Mexico, Mexico (in front of Sisal and Puerto Progreso, Yucatán).

\section{Material and methods}

Amphipods were collected in the SAS, which is located W to Puerto Progreso, Yucatan, SE Gulf of Mexico. This is 


\section{References}

Azman, B.A.R. (2009) Cyproideidae. In: Lowry, J.K. \& Myers, A.A. (Eds.), Benthic Amphipoda (Crustacea: Peracarida) of the Great Barrier Reef, Australia. Zootaxa, 2260, 380-392.

Barnard, J.L. (1972) Gammaridean Amphipoda of Australia, Part I. Smithsonian Contributions to Zoology, 103, 1-333. http://dx.doi.org/10.5479/si.00810282.103

Barnard, J.L. \& Karaman, G.S. (1991) The families and genera of Marine Gammaridean Amphipoda (Except Marine Gammaroids). Records of the Austrlian Museum, Suppl. 13 (parts 1 and 2), 1-866. http://dx.doi.org/10.3853/j.0812-7387.13.1991.367

Griffiths, C.L. (1975) The Amphipoda of Southern Africa. Part 5. The Gammaridea and Caprellidea of the Cape Province west of Cape Agulhas. Annals of the South African Museum, 67, 91-181.

LeCroy, S.E., Gasca, R., Winfield, I., Ortiz, M. \&Escobar-Briones, E. (2009) Amphipoda (Crustacea) of the Gulf of Mexico. In: Felder, D. \& Camp, D.K. (Eds.), Gulf of Mexico: Its Origin, Waters and Biota. Vol . I. Biodiversity of Gulf of Mexico. Texas A\&M University Press, USA, pp. 941-972.

Lowry, J.K. \& Stoddart, H.E. (2003) Crustacea (Malacostraca: Peracarida) Amphipoda, Cumacea and Mysidacea. In: Beesley, P.L. \& Houston, W.W.K. (Eds.), Zoological Catalogue of Australia. Vol. 19.2B. CSIRO Publishing, Melbourne, Australia, $531 \mathrm{pp}$.

Lowry, J.K. \& Azman, B.A.R. (2008) A new genus and species of cyproideid amphipod associated with unstalked crinoids on the Great Barrier Reef, Australia. Zootaxa, 1760, 59-68.

Moore, P.G. (1981) Marine Amphipoda (Crustacea) new to science from the Tasmanian phytal fauna. Journal of Natural History, 15, 939-964. http://dx.doi.org/10.1080/00222938100770701

Myers, A.A. (1985) Shallow water, coral reef and mangrove amphipoda (Gammaridea) of Fiji. Records of the Australian Museum, Suppl 5, 1-143. http://dx.doi.org/10.3853/j.0812-7387.5.1985.99

Ortiz, M., Lalana, R. \& Sánchez-Díaz, A. (2000) Una nueva especie de anfípodo espongícola del género Hoplopheonoides Shoemaker, 1956 (Gammaridea, Cyproideidae) de Cuba, Avicennia, 12/13, 63-68.

Potts, F.A. (1915) The fauna associated with the crinoids of a tropical coral reef: with especial reference to its color variations. Papers of the Department of Marine Biology, Carnegie Institute Washington, 8, 71-96.

Thomas, J.D. (1999) Moolapheonoides utmas, new species, from coral reefs in the Madang Lagoon, Papua New Guinea (Amphipoda, Cyproideidae). Bulletin of Marine Science, 65 (2), 515-521. 